\title{
Study of the phreatic aquifer behavior in the Mansões Santo Antônio neighborhood, Campinas - SP.
}

\section{Eloise Cristina Santos*, Ana Elisa Silva de Abreu.}

\begin{abstract}
The groundwater monitoring wells that exist in the Mansões Santo Antônio neighborhood have been used for water level and hydraulic conductivity measurments in order to sstudy groundwater recharge. The collected data showed variations of the hydraulic heads in amplitudes over 4 meters and less than 1 meter during the monitoring time (2017 to 2019). The behavior of the groundwater levels is associated to characteristics such as well depth and discrepancies in the rainfall distribution thorughout the years.
\end{abstract}

Key words: Hydrogeology, Groungwwater Recharge, Water Table Monitoring.

\section{Introduction}

The Mansões Santo Antonio neighborhood is an example of the rapid urban advance, due to the industrial and demographic growth of the city over the last decades. The area is interesting for the study and monitoring of the local aquifer, since it is a site that was contaminated by organochlorines during industrial activities in the 1970s to 1990s. The neighborhood has undergone environmental investigation and has a series of well monitoring systems, which enable water level measurements.

The aim of this work is to study the behavior of the groundwater in the local phreatic aquifer, in order to obtain data for the estimation of groundwater recharge in the study area, as well as conducting slug tests for estimating hydraulic conductivity.

\section{Results and Discussion}

The results of the water level monitoring are presented in Figure 1. The water level curves show different amplitudes due to effects of seasonality, recharge behavior and also rainfall index.

Monitoring dates (days)

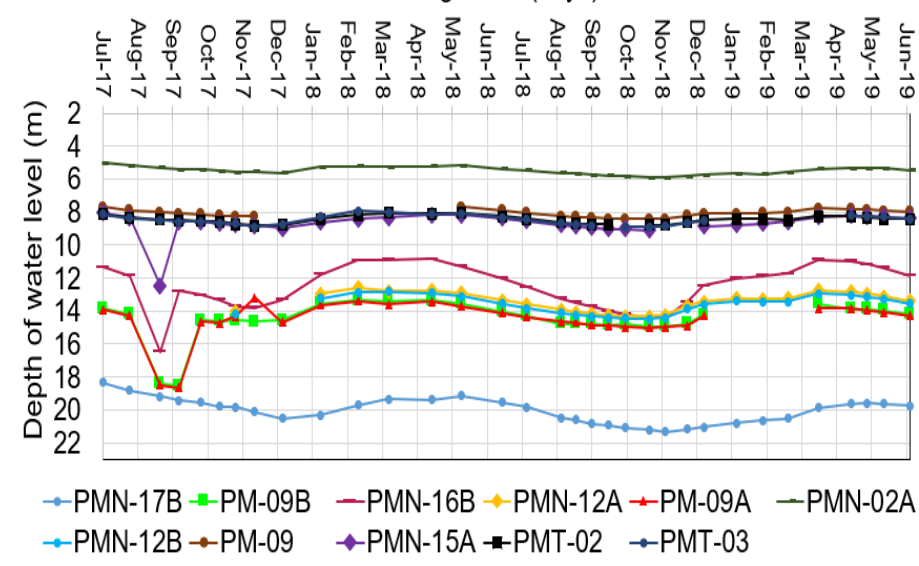

Figure 1. Variation of water levels during the monitoring time.

The lowering of hydraulic heads corresponds to the lesser rainfall in winter. According to data from CEPAGRI (2019), the drought period of 2017 was more intense than the drought period of 2018 . In July 2017, there was no precipitation compared to the more distributed rains in the winter of 2018. This explains the 4 meters lowering of hydraulic heads in 2017 and the less intense lowering in 2018.

The results of the slug tests are presented in Chart 1, along with some construction characteristics of the monitoring wells. Wells that showed hydraulic head variation amplitudes over 4 meters have depths around 20 meters and the regolith is composed of silty sand and sandy silt. The wells with amplitude lower than 1 meter have depths around 10 meters and the regolith around them is composed of sandy silt.

Chart 1. Characteristics of the study wells and hydraulic conductivity estimated from slug tests.

\begin{tabular}{|c|c|c|c|}
\hline Well & Depth $\mathbf{( m )}$ & Regolith & $\begin{array}{c}\text { Hydraulic } \\
\text { Conductivity } \mathbf{( c m} / \mathbf{s})\end{array}$ \\
\hline PM-09A & 20,00 & Silty sand & $1,36 \mathrm{E}-03$ \\
\hline PM-09B & 25,10 & Silty sand & $1,27 \mathrm{E}-03$ \\
\hline PM-09 & 12,00 & Sandy silt & $1,81 \mathrm{E}-04$ \\
\hline PMT-02 & 10,00 & Sandy silt & $8,61 \mathrm{E}-04$ \\
\hline PMT-03 & 10,00 & Sandy silt & $2,39 \mathrm{E}-04$ \\
\hline PMN-17B & 28,50 & Silty sand & $2,47 \mathrm{E}-04$ \\
\hline PMN-16B & 21,30 & Sandy silt & $3,61 \mathrm{E}-04$ \\
\hline PMN-15A & 18,15 & Sandy silt & $1,70 \mathrm{E}-04$ \\
\hline PMN-02A & 14,70 & Sandy silt & $5,74 \mathrm{E}-04$ \\
\hline PMN-12A & 20,54 & Silty sand & $1,64 \mathrm{E}-04$ \\
\hline PMN-12B & 13,20 & Silty sand & $7,13 \mathrm{E}-02$ \\
\hline
\end{tabular}

\section{Conclusions}

The study of the hydraulic heads and conductivities of the phreatic aquifer in the Mansões Santo Antonio neighborhood lead to the identification of variations of the hydraulic heads in amplitudes over 4 meters to less than 1 meter. This behavior was associated with the depth of the well (deeper wells showed larger variations) and the discrepancies in the pluviometric distribution between 2017 and 2019.

AECOM. Investigação Ambiental Detalhada e Avaliação de Risco à Saúde Humana - Mansões Santo Antônio. Campinas: Prefeitura Municipal, 2013.

CEPAGRI. Climatologia Campinas: Comparação/ Precipitação. [S. 1.], 2019. Available in: https://www.cpa.unicamp.br/graficos. Access in: 29 jun. 2019. 